\title{
Determining Unemployment Factors Among Job Seeking Youth in the East Coast of Peninsular Malaysia*
}

\author{
Elia Syarafina Abdul SHAKUR', Nor Hayati SA'AT², Nazli AZIZ \\ Siti Salina ABDULLAH ${ }^{4}$, Nor Hafzan Abd RASID ${ }^{5}$
}

Received: September 01, 2020 Revised: October 26, 2020 Accepted: November 05, 2020

\begin{abstract}
This study examines factors of unemployment and career path challenges commonly faced by youth in the East Coast of Peninsular Malaysia. The study employed a quantitative approach which involved a total of 1,083 youths in Kelantan, Pahang and Terengganu selected at random. Descriptive and multiple regression analysis (OLS) methods were used to analyze demographic distribution of youth in determining factors influencing unemployment among them. The results reveal that the majority of youth respondents in the East Coast states of Malaysia are still unemployed and actively seeking employment. Demographic profiles are based on the survey results, youths seeking employment with 36 per cent distribution in Kelantan, 34 per cent in Pahang, and 30 per cent in Terengganu. Majority of the respondents were youths aged 20 to 24 years with a 40.9 percent percentage. The findings show that there are differences in factors affecting youth unemployment in the three states of East Coast, Malaysia. For Kelantan (age, experience, work mobility, marital status), Pahang (experience, marital status) and Terengganu (experience, gender, marital status, training). This study suggests that youths should be wise in preparing for their career by choosing the right career as well as doing side jobs to gain experience before they pursue for a real job.
\end{abstract}

Keywords: Youth Unemployment, East Coast, Job Seekers, Career Planning, Mobility

JEL Classification Code: J6, J64, J13, J11, R230

\section{*Acknowledgements:}

This article is part of the completed work funded by Khazanah Research Institute (KRI), Malaysia. The author also would like to express deepest appreciation to Institute of Tropical Biodiversity and Sustainable Development (BIO-D TROPICAL) and Faculty of Business, Economics and Social Development (FPEPS), University of Malaysia Terengganu.

${ }^{1}$ First Author and Corresponding Author. Researcher, Institute of Tropical Biodiversity and Sustainable Development, Universiti Malaysia Terengganu, Malaysia [Postal Address: Universiti Malaysia Terengganu, 21030, Kuala Nerus, Terengganu, Malaysia] Email: eliasya@umt.edu.my

2[1] Faculty of Business, Economics and Social Development, Universiti Malaysia Terengganu, Malaysia. [2] Institute of Tropical Biodiversity and Sustainable Development, Universiti Malaysia Terengganu, Malaysia. Email: norhayati@umt.edu.my

${ }^{3}$ Faculty of Business, Economics and Social Development, Universiti Malaysia Terengganu, Malaysia. Email: nazli_aziz@umt.edu.my ${ }^{4}$ Faculty of Business, Economics and Social Development, Universiti Malaysia Terengganu, Malaysia. Email: ctsalina@umt.edu.my

${ }^{5}$ Faculty of Business, Economics and Social Development, Universiti Malaysia Terengganu, Malaysia. Email: norhafzanrasid@gmail.com

(c) Copyright: The Author(s)

This is an Open Access article distributed under the terms of the Creative Commons Attribution Non-Commercial License (https://creativecommons.org/licenses/by-nc/4.0/) which permits unrestricted non-commercial use, distribution, and reproduction in any medium, provided the original work is properly cited.
origited

\section{Introduction}

Malaysia has an estimated population of 32.6 million people (2019) with an annual growth rate of $0.6 \%$ (Department of Statistics Malaysia, DOSM, 2019a). The total population was categorized by three age groups of 7.6 million (23.3\%) for the age group of 14 years and below; 22.8 million $(70 \%)$ for 15 - 64 year olds; and 2.2 million $(6.7 \%)$ over 65 years of age. This category indicates that Malaysia has a productive figure of population.

Youth in Malaysia refers to age group of between 15 and 40 years under Youth Association Act and Youth Development 2007 - Act 668. However, starting 2018, the youth will be defined as individuals aged between 15 to 30 years in the Malaysian Youth Policy 2015 (IYRES, 2017). According to that definition, the youth group for 2019 in Malaysia (15-40 years) represents 14.871 million people. Specifically, in 2019 the number of youths in three states of the East Coast of Peninsular Malaysia namely Kelantan (416,500 people), Pahang (425,000 people) and Terengganu $(286,600)$ is 1.128 million. This represents $7.6 \%$ of the East 
Coast population with a total population of 2.545 million (IYRES, 2019). However, this study only considered the youth category between 18 and 29 years old for the purpose of analysis. Ages 18 - 29 years were used as study sample because they were found to be productive and active groups seeking employment in the East Coast of Peninsular Malaysia. Meaning youth aged 17 and below are excluded from this study. This exemption is based on the assumption that they need to complete compulsory secondary education at Certificate of Education Malaysia (SPM) level.

The unemployment rate in Malaysia until October 2019 was $3.2 \%$ with a total of 512,100 unemployed people $(3.2 \%)$ (DOSM, 2019c). Meanwhile, the unemployment rate in Malaysia in 2018 is 514,200 people (3.3\%). This figure shows a decrease of $(0.1 \%)$ unemployment rate in 2019 compared to 2018. From that amount, youths aged between 20 to 24 represent $11.9 \%$ and between 25 to 29 years old by $4.5 \%$ (MoF, 2019). On the other hand, in terms of gender, the unemployment rate among men is generally lower by $19.6 \%$ compared with women at $44.8 \%$ (DOSM, 2018a). For ethnic group, Bumiputera recorded the highest percentage (69.3\%), Chinese (22.8\%), Indians (6.9\%) and others (1.0\%) in 2019 (DOSM, 2019b). Meanwhile, the unemployment rate on the East Coast showed higher trends than the national unemployment rate of $4.6 \%$ in 2017 and 3.3\% in 2018 of the total population. On the other hand, there was an increase of unemployment in Terengganu (2017: 6.3\%; 2018: 7.3\%) and Kelantan (2017: 5.6\%; 2018: 6.0\%). In contrast to the state of Pahang, the unemployment rate has declined (in 2017: 4.2\%; in 2018: 3.7\%) on an annual basis. In 2018, the states of Terengganu and Kelantan were among the top five states with unemployment while nine states recorded unemployment below 4.0 percent including Pahang (3.7\%) (IYRES, 2017; DOSM, 2018b).

Recent statistics show various factors contributing to unemployment among youth in Malaysia. According to the
Ministry of Finance (2019), unemployment among youth is due to i) lack of work experience, ii) lack of skills, iii) insufficient education levels, and iii) skills incompatibility to compete in the labor market. Instead, employers place communication as the most important skill in the hiring process followed by work experience, interpersonal skills as well as passion and commitment. The factors of youth unemployment are not new but have become major issues that need to be looked at. Based on such factors, this study will analyze in-depth and specifically youth groups in the East Coast. Do unemployment factors in the study area show the same trend as the national level? Are there any different and distinctive factors in the East Coast as compared to the national level? Why is youth unemployment in the East Coast lower or higher?.

\section{Theory of Youth Career}

Planning and choosing a career is a complex process. This process continues from birth to the old age based on the Super Career Theory (Super, 1969). While Ginzberg (1972) argues that career selection begins before individuals reach the age of 11 until the age of 17 and above. Therefore, the process of career selection needs to be carefully planned to ensures the best option of career and guarantees the wellbeing of the individual (Ismail et al., 2019).

The basis for a good career choice is the need for personal information and clear career path. Parson (1909) through Trait Theory and Factors outlines the three stages that an individual must go through in deciding good career choice. First, each individual needs to understand and explore personality traits. Second, the individual has clear career information and knowledge. Next, individuals customize or match personal and career information to make appropriate career choices. Figure 1 is a summary of career selection process based on Trait Theory and Factors:

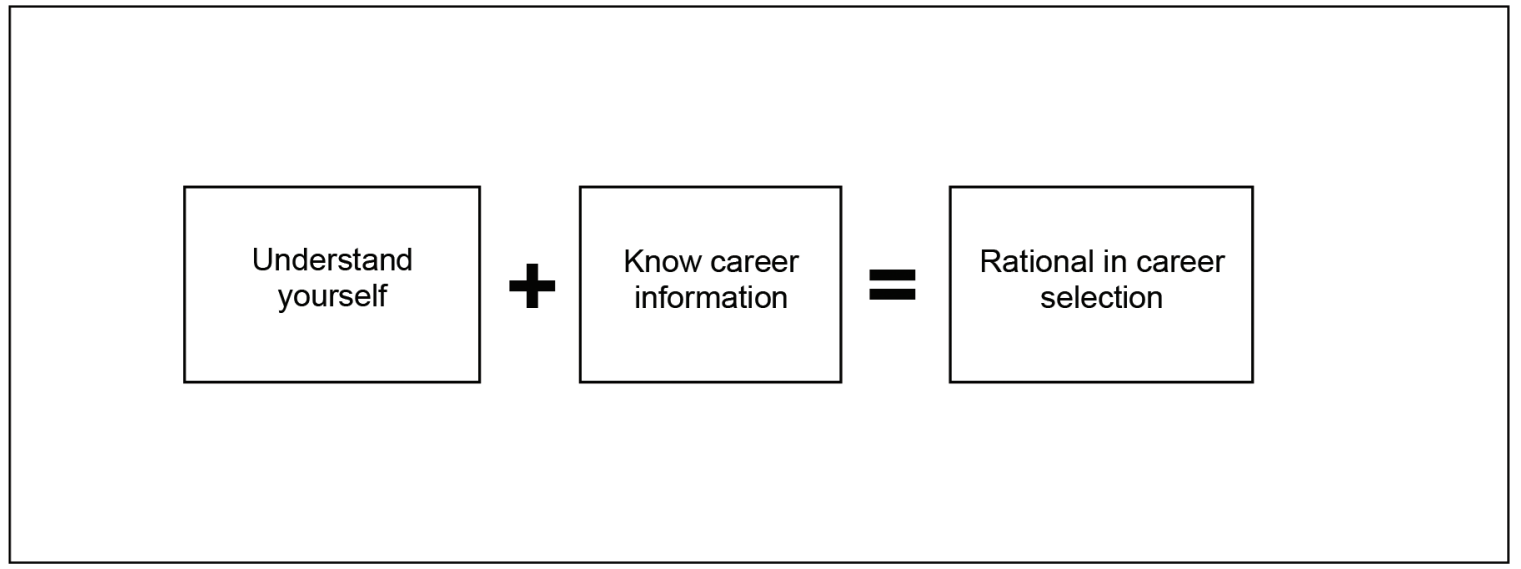

Figure 1: Career selection based on Trait Theory and Factors 
According to Trait Theory and Factors, personal trait is the first step for individuals to make career choices. However, this theory does not take into account other factors such as interest, value, aptitude, and achievement (Sharf, 2000). Looking at today's career challenges, a number of other aspects need to be taken into account by individuals in making career choices which include career assurance (Stanley et al., 2014), individual maturity (Mansor and Rashid, 2016) and understanding of job market expectations (Hooker and Brand, 2010), thus enabling individuals to make proper career planning and selection for them to obtain a career that not only suits them and their personality but also provides a source of income for individuals to continue living (Mustapa and Abdullah, 2019).

\section{Literature Review}

\subsection{Discussion of Previous Studies on Unemployment Among Youth}

\subsubsection{Location and Work Mobility}

Youth in rural areas have disadvantages in terms of low job opportunities, income inequality, and women find it difficult to find employment compared to youth in the cities. Generally, rural people are dominated by the B40 group (below RM4,850) who find it challenging entering the labor market, lack of information about job opportunities, absence of close contact for jobs and lower wages. Lower education levels resulted in rural youths are more likely to find employment at a younger age than urban residents (Xiaoya and Tay, 2016). Urban youth are more likely to pursue higher education to secure better job opportunities in the long run at management and professional levels.

Lack of job opportunities and rural poverty lead to a tendency of productive youth for work mobility or migration to the bigger cities. The phenomenon of migration of active youth groups from rural to urban areas in search of job opportunities is nothing new. The mobility of rural-to-urban mobility began as early as Industrial Industry in the 19th century. In Malaysian context, the migration of productive populations to major cities, especially to Kuala Lumpur, has been increasing since the 1980 s to the present (Hussain et al., 2015).

Work mobility is a response to new job opportunities, especially access to social networks. Lancee (2019) describes young people migrating to the city as a result of low unemployment and low wages in rural areas. Xiaoya and Tay (2016) stated that rapid urbanization has led to an increasing number of migrants to cities. Migrants in the cities exhibit important features that distinguish rural youth immigrants who lack education and are under skilled. While Mol (2016) considered that urban youth migration aims to improve their personality status in the long run. In Europe, there is a changing trend in which women are more likely than men to emigrate nowadays (European Commission, 2014) compared to earlier times (Vandenbrande et al., 2006).

\subsubsection{Age, Gender and Marital Status}

Demographic factors (gender, age, nationality, marital status and dependency), job experience and job search activities were considered as variables for employment (Yerkes et al., 2012). In terms of age, there is a difference in the experience of youth leaving school and starting work at the age of 18 with 7 years of work experience. Meanwhile, youths who leave school at age 23 have 2 years' experience (Haar, 2018) if they apply for the same type of employment when they are 25 years old. Moreover, Tåhlin and Westerman (2020) stated that job competition for basic skills by age difference is by looking at work experience and job position of the applicant as a productive indicator. As for gender, the Ministry of Finance (2019) has stated that women's labor participation rates should be increased to balance labor shortages. Women are more likely to join the labor force (Wulandari et al., 2019; Kamaruddin et al., 2020) if there are family-related needs. Thus, demographic factors in terms of age, gender, and marital status may influence unemployment.

\subsubsection{Family Background}

The socioeconomic status of youth is often defined by their parents' position in the labor market, their educational status or their income (Lögdberg et al., 2018). According to Zwysen and Longhi (2018), there are four occupational categories that determine socioeconomic status of a family: management and professional (high class) jobs; supervisory and technical jobs for the middle and low (middle class); part-day or daily work (working class); and self-employed. Furthermore, the socio-economic background of parents can directly and indirectly influence the labor market. For example, high-income parents will share their 'soft skills' with their children being evaluated in the labor market. In other words, the social status of youth parents' social networks will affect the marketability of individuals involved in the job search (Patacchini and Zenou, 2012). The views of Patacchini and Zenou (2012) are still relevant in the Malaysian context as the most unemployed in the country for working-age youth with academic qualifications are B40 (low-income) family graduates (MoF, 2019).

\subsubsection{Education, Training and Work Experience}

The ratio of job vacancies to job seekers for university and college graduates has improved but is still low. There 
are still a number of graduates who are unemployed (Xiaoya and Tay, 2016). According to a report by the Ministry of Finance (2019), 1.4 million vacancies in Malaysia comprised of unskilled $(86.9 \%)$ and semi-skilled $(8.4 \%)$ jobs. Meanwhile, vacancies for skilled groups with tertiary qualification were only $4.7 \%$ or 64,402 from the total number.

Tåhlin and Westerman (2020) explained that the recruitment criteria vary according to the individual skill level. Specifically, they are asked to emphasize the importance of education and work experience as the basis for their decision-making. Employers position their prospective employees according to their suitability for successful job completion. Generally, job shifts are caused by individuals seeking to find a position that fits their skills or expertise (Dorsett and Lucchino, 2015). According to Tåhlin and Westerman (2020), differences in educational categories are often seen as indicators of productive capacity, thus determining where individuals are in line with job applicants. Records of data for access to resources and economics are crucial to ensure that both current unemployment and work experience at university are recognized by employers for reference (Roberts and Zhen, 2017). According to Stuth and Jahn (2020), lack of work experience is one of the major obstacles that prevent young people from getting a job. In this regard, there is a stream of youths leaving their studies to seek work experience. Longhi and Taylor (2013) stated that in hiring, employers cannot see the productivity of potential job applicants as they can only interpret unemployment as a sign of weak productivity. When an employer receives applications from a job seeker with work experience and a job seeker who is unemployed, the employer will prefer a job applicant with work experience (Eriksson and Gottfries, 2005). Work experience is important and will influence the employer's preference to hire such candidates as their staff.

Apart from experience, skill factor is also one of the major causes of unemployment rates for university graduates. A study by the World Bank and the Talent Corporation shows that less than $10 \%$ of companies have experience in developing a university curriculum or program (MoF, 2019). According to Kruppe and Lang (2018), several types of public sponsorship training programs were introduced for job seekers that aimed at increasing participants' human capital, thus supporting reintegration into the labor market. The job seeker involved in this training will decide which job is best for them. Next, job seekers who are still unemployed should focus on job and industry characteristics to increase demand for skilled labor, so that participants will get a new job once completing their courses. According to Tåhlin and Westerman (2020), low-skilled jobs are important for youths who need them to enter the labor market. In terms of finding a job, job seekers who are unemployed and job seekers with working experience will have the potential to enter the labor market with a wealth of knowledge, skills and abilities called 'skills'. It is combined with the results of individual choice in terms of education, training and work experience (World Economic Forum (WEF), 2014). The demand for skill is being commercialized by the labor market to be more intensive not only in the private sector but also in the government sector in addressing employment challenges (Pheko and Molefhe, 2017).

The importance of considering other mechanisms such as lack of career training may hinder a job seeker to find a suitable job after graduation. There are other differences in the competitiveness of minority of graduates that are not observed here, such as co-curriculum activities or soft skills that cannot be seen (Hamed et al., 2015; Zwysen and Longhi, 2018). Training is important before entering the workforce to gain work experience related to job in pursuit.

\subsection{Critical Perspective About Youth Unemployment Status and Working Conditions in The Labour Market}

Critical perspective on the way that was discussed by KRI (2018) and supported by other sources. Firstly, evidence of skills-jobs mismatch prominent in School to Work Transition Survey Community (SWTS). In line with the evidence of skill mismatch, the current occupation and employment sector of young workers are not what many prefer or would ideally want. One-third are service and sales workers but only $3 \%$ identify this as their preferred occupation. While $6 \%$ are in business related occupations, such occupations represent the preferred choice of a third of all young workers. The strongest preference $(38 \%)$ is for professional occupations but only a quarter of all young workers have professional jobs and the percentages of those working in online businesses, civil service, education, health and social work are smaller than the indicated preference for these sectors (Carabelli and Lyon, 2016; Wilde and Leonard, 2018; MIDF, 2018).

Secondly, poor economic conditions, excessive competition, lack of credit and harassment by the authorities are the problems identified by own-account workers, while the young employers cite high labour costs and lack both skilled and unskilled workers. At least $90 \%$ of all selfemployed workers claim that they have never received any kind of government assistance, despite the plethora of government incentives and funding for SMEs (Camba, 2020). In fact, only $30 \%$ of all young self-employed are even aware of where they can get support for their economic activities. The support they most wish to have is financial assistance (Bakar and Bakar, 2020), followed by access to 
capital and tax reductions or exemptions (Hedvicakova, 2018).

Third, employers play a limited role in enhancing youth employability. It is not just education and training institutions that are responsible for efforts to improve employability; employers have key roles to play. However, almost three-quarters of all enterprises surveyed do not have training budgets; their participation in employability training programmes for youth is very low; and they have limited interaction with education and training institutions to share their views on what and how students should be learning to enhance their employability (Aida et al., 2015).

Lastly, among the paid employees, the regular fulltime workers are more likely to be hired by private limited companies and government agencies, while the temporary, part-time or casual workers tend to be hired by sole proprietors who often operate smaller enterprises. More than half of all paid employees claim they receive training provided by their employers, not only for the basic job requirements but also for upgrading their current skills, acquiring new skills and using new technologies - suggesting that employers are investing in these young workers and there could be opportunities for career advancement. When asked about employer preferences, they feel that employers prefer hiring those with work experience but have less distinct preferences regarding gender, age or language competencies of young workers (Cassells and Duncan, 2020).

\section{Research Methodology}

The study used a survey design with a sample of 1,083 respondents in three states in the East Coast of Malaysia namely Kelantan, Pahang and Terengganu. The respondents of the study involved youths aged 18-29. The selection of this age is consistent with the purpose of this study. The sample size and location of the study were randomly selected by justifying that they were sufficient to represent the population and to meet the scope of the study.

The survey research designed in this study involved questionnaire instrumentation as a primary data collection method. This form contains four sections that the respondents need to fill in: Part A: Background Information, Part B: Youth Looking for Work - Education and Training, Part C: Youth Finding Jobs - Finding Jobs and Part D: Opinions and Youth Aspiration.

Next, to analyze unemployment factors and youth career challenges in the East Coast, descriptive and inferential statistics were used. Descriptive statistics include frequency, percentage, mean and variance values to see respondents' demographic distribution. While inferential statistics involve a Multiple Linear Regression Analysis (MLR) to examine the factors influencing youth unemployment in the East Coast.
Important factors affecting youth unemployment were estimated using the Multiple Linear Regression Analysis (MLR) method. Multivariate Regression Analysis (MLR) on the factors contributing to the unemployment period of the respondents aims at estimating the factors that contribute to the unemployment period/career path of the respondents. The duration of unemployment representing the dependent variables can be measured based on the average length of time taken by unemployed respondents who are looking for a job. The independent variables identified were demographic factors such as location of residence, age, gender, marital status, family background, education level and training/career course factors, work experience and youth mobility factors. Through the Abugamea (2018) formula, the results are used to form multiple regression equations as follows:

$$
\begin{aligned}
\mathrm{Y}= & \beta_{0}+\beta_{1} X_{1}+\beta_{2} X_{2}+\beta_{3} X_{3}+\beta_{4} X_{4}+\beta_{5} X_{5}+\beta_{6} X_{6}+\beta_{7} X_{7} \\
& +\beta_{8} X_{8}+\beta_{9} X_{9}+\varepsilon_{t} \cdots \cdots \cdots \cdots \cdots \cdots \cdots \cdots \cdots \\
\mathrm{TP}= & \beta_{0}+\beta_{1} L O C_{1}+\beta_{2} G E N_{2}+\beta_{3} M S_{3}+\beta_{4} F A M_{4} \\
& +\beta_{5} E D U_{5}+\beta_{6} T R_{6}+\beta_{7} E X P_{7}+\beta_{8} A G E_{8}+\beta_{9} M G_{9} \\
& +\varepsilon_{t} \cdots \cdots \cdots \cdots \cdots \cdots \cdots \cdots
\end{aligned}
$$

Where Y/TP refers to the dependent variables are the period of unemployment of the respondent, X1/LOC: the place of residence of the respondent, X2/GEN: the gender of the respondent, $\mathrm{X} 3 / \mathrm{MS}$ : the marital status of the respondent, X4/FAM: family background, X5/EDU: respondent's educational level, X6/TR: the status of training or career course attended by the respondent, X7/EXP: level of work experience of the respondent, X8/AGE: age of respondent and X9: MG: factor of migrant level. While $\beta_{0}$ refers to the constant (Y-intercept), $\beta_{1}-\beta_{9}$ represents the elasticity of the parameter and $\varepsilon_{t}$ is the error found in this regression model. To facilitate the process of interpreting the results of the study, the multiple regression equation 1 was developed into a new form of equation 2 and was further developed in the results.

\subsection{Conceptual Framework}

Nine factors of unemployment are proposed to develop the conceptual framework of this study. The independent variables proposed include location, age, gender, marital status, family background, education, training, work experience and work mobility. Meanwhile the dependent variable refers to period of unemployment faced by the youth group.

Figure 2 shows the conceptual framework of the study developed to study the factors influencing youth unemployment in the East Coast as a challenge in determining their career path. 


\begin{tabular}{|l|}
\hline \multicolumn{1}{|c|}{ Independent Variables } \\
\hline Location \\
\hline Age \\
\hline Gender \\
\hline Marital Status \\
\hline Family Background \\
\hline Education \\
\hline Training \\
\hline Work Experience \\
\hline Work Mobility \\
\hline
\end{tabular}

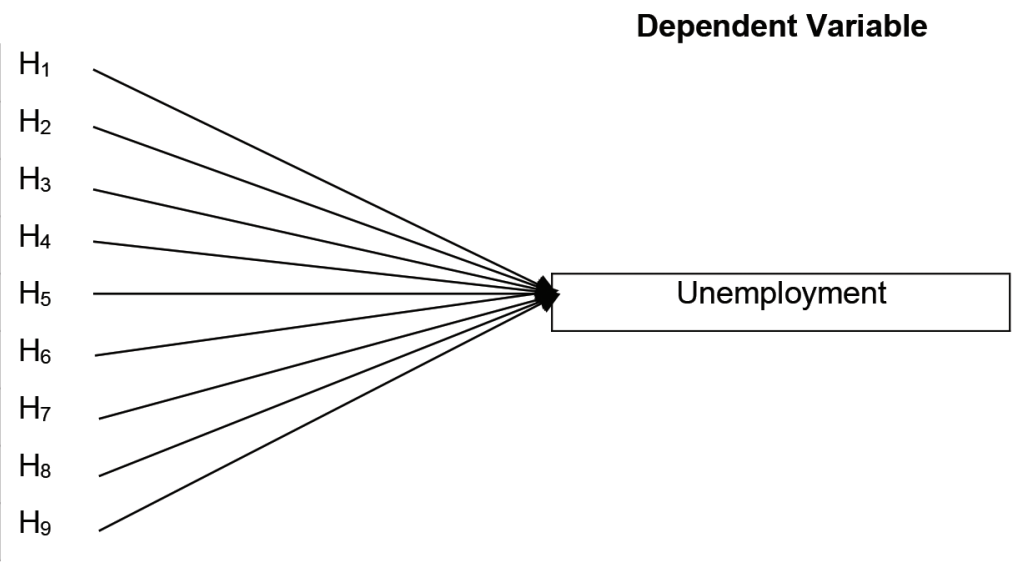

Figure 2: Proposed Conceptual Framework - Factors Influencing Unemployment for the East Coast in Malaysia

\section{Findings}

\subsection{Profile of Youth Job Seekers}

Findings of the respondents' demographic profiles are based on the survey results of 1,083 youths seeking employment from states in the East Coast of Malaysia with 36 per cent distribution in Kelantan, 34 per cent in Pahang, and 30 per cent in Terengganu. Results of descriptive statistical analysis of the respondents 'demographic profiles are as shown in Table 1. Of these, the respondents' gender was 58.1 percent female and 41.9 percent male. Respondents involving more female youths were obtained because this sample considered the proportion of female gender population in Malaysia to be higher than men. Majority of the respondents were youths aged 20 to 24 years with a 40.9 percent percentage and bachelor status (91.2 percent). In terms of education level, the majority of respondents had a secondary school certificate (SPM) (43.5\%). This was followed by a bachelor's degree (25.3\%) and a Malaysian Higher School Certificate (STPM)/Diploma (25.2\%). Most youths lived in urban areas $(56.5 \%)$ compared to rural (43.5\%).

For the level of work experience, majority of respondents who have no work experience but are actively looking for a job is 49.3 percent ( 534 people). The remaining 30.0 percent have work experience but are unemployed. From that figure, Kelantan state has the highest number of unemployed youths at 208 (19.2 percent) compared to Pahang (200: 18.5 percent) and Terengganu (126: 11.6 percent). The findings indicate that majority of the youth respondents in the East Coast are unemployed but have clear career plan for employment (Table 1).

Descriptive analysis on experience of attending course or career training as an initiative for employment indicates that
68.7 percent (744 people) from the three states have never participated in any career training/training as preparation for employment. Another 31.3 percent have attended career/ training courses. This finding also shows that there is no significant difference in the number of youth respondents attending this course for all the three states in the East Coast. Each state recorded a similar percentage. The findings are in line with Table 2 findings showing that unemployed youth are youth who have never attended any career course/ training.

For the most recent/current job status, most respondents were unemployed (49.3 percent). The highest percentage was recorded in Kelantan with an unemployment rate of 208 people (19.2 percent). The figure was followed by Pahang and Terengganu by 18.5 per cent and 11.6 per cent respectively. Meanwhile, 18.2 percent of the respondents were fulltime workers. Only a small proportion of the respondents' youth worked full-time (12.1 percent). From a total of 534 unemployed and inexperienced respondents, the majority (26.0 percent: 139) stated that they took three to six months to get a job (Table 4). The findings also indicate that some of the youth respondents (13.3 percent: 71) took longer than one year to be employed. The shortest period of employment was less than one week with a percentage of 12.4 percent (66 persons) (Table 4). This finding indicates that duration of employment is closely related to the respondents' work experience.

\subsection{Multiple Linear Regression Analysis (MLR)}

Next, to analyze the factors influencing youth unemployment in the East Coast, Multiple Linear Regression Analysis (MLR) was conducted. The results of the estimation for the MLR model are shown in Table 9. The model was developed to test the following hypotheses: 
Table 1: Demographic Profile of Youth Job Seekers by State in the East Coast

\begin{tabular}{|c|c|c|c|c|c|}
\hline $\begin{array}{l}\text { Demographic } \\
\text { profile }\end{array}$ & Item & Kelantan (\%) & Pahang (\%) & Terengganu (\%) & Total (\%) \\
\hline \multirow{3}{*}{ Gender } & Male & $176(16.3)$ & $154(14.2)$ & $124(11.4)$ & $454(41.9)$ \\
\hline & Female & $210(19.4)$ & $216(19.9)$ & $203(18.7)$ & $629(58.1)$ \\
\hline & Total & $386(35.6)$ & $370(34.2)$ & $327(30.2)$ & $1083(100.0)$ \\
\hline \multirow{4}{*}{ Age } & 18 to 20 years & $140(12.9)$ & $135(12.5)$ & $7(0.6)$ & $282(26.0)$ \\
\hline & 20 to 24 years & $150(13.9)$ & $163(15.1)$ & $130(12.0)$ & $443(40.9)$ \\
\hline & 25 to 29 years & $96(8.9)$ & $72(6.6)$ & $190(17.5)$ & $358(33.1)$ \\
\hline & Total & $386(35.6)$ & $370(34.2)$ & $327(30.2)$ & $1083(100.0)$ \\
\hline \multirow{3}{*}{ Location } & City & $181(16.7)$ & $205(18.9)$ & $226(20.9)$ & $612(56.5)$ \\
\hline & Rural & $205(18.9)$ & $165(15.2)$ & $101(9.3)$ & $471(43.5)$ \\
\hline & Total & $386(35.6)$ & $370(34.2)$ & $327(30.2)$ & $1083(100.0)$ \\
\hline \multirow{4}{*}{ Marital Status } & Single & $362(33.4)$ & $357(33.0)$ & $296(27.3)$ & $1015(93.7)$ \\
\hline & Married & $23(2.1)$ & $13(1.2)$ & $31(2.9)$ & $67(6.2)$ \\
\hline & Divorced & $1(0.1)$ & - & - & $1(0.1)$ \\
\hline & Total & $386(35.6)$ & $370(34.2)$ & $327(30.2)$ & $1083(100.0)$ \\
\hline \multirow{8}{*}{ Education Level } & No formal education & $2(0.2)$ & $1(0.1)$ & $1(0.1)$ & $4(0.4)$ \\
\hline & Primary School & $4(0.4)$ & $3(0.3)$ & $3(0.3)$ & $10(0.9)$ \\
\hline & Lower Secondary School & $9(0.8)$ & $2(0.2)$ & $2(0.2)$ & $13(1.2)$ \\
\hline & Upper Secondary School & $209(19.3)$ & $196(18.1)$ & $66(6.1)$ & $471(43.5)$ \\
\hline & STPM/ Diploma & $68(6.3)$ & $111(10.2)$ & $94(8.7)$ & $273(25.2)$ \\
\hline & Skill Certificate/ Vocational & $13(1.2)$ & $11(1.0)$ & $14(1.3)$ & $38(3.5)$ \\
\hline & Bachelor/ Masters/ Phd & $81(7.5)$ & $46(4.2)$ & $147(13.6)$ & $274(25.3)$ \\
\hline & Total & $386(35.6)$ & $370(34.2)$ & $327(30.2)$ & $1083(100.0)$ \\
\hline \multirow{4}{*}{$\begin{array}{l}\text { Family } \\
\text { Background }\end{array}$} & Poor & $70(6.5)$ & $57(5.3)$ & $79(7.3)$ & $206(19.0)$ \\
\hline & Middle class & $310(28.6)$ & $296(27.3)$ & $243(22.4)$ & $849(78.4)$ \\
\hline & Well-off/rich & $6(0.6)$ & $17(1.6)$ & $5(0.5)$ & $28(2.6)$ \\
\hline & Total & $386(35.6)$ & $370(34.2)$ & $327(30.2)$ & $1083(100.0)$ \\
\hline \multirow{4}{*}{$\begin{array}{l}\text { Working } \\
\text { Experience }\end{array}$} & None, first time & $208(19.2)$ & $200(18.5)$ & $126(11.6)$ & $534(9.3)$ \\
\hline & Worked before but currently unemployed & $108(10.0)$ & $95(8.8)$ & $122(11.3)$ & $325(30.0)$ \\
\hline & Working but looking for another job & $70(6.5)$ & $75(7.0)$ & $79(7.3)$ & $224(20.7)$ \\
\hline & Total & $386(35.6)$ & $370(34.2)$ & $327(30.2)$ & $1083(100.0)$ \\
\hline \multirow{3}{*}{$\begin{array}{l}\text { Career training / } \\
\text { courses }\end{array}$} & Never & $266(24.6)$ & $278(25.7)$ & $200(18.5)$ & $744(68.7)$ \\
\hline & Used to attend & $120(11.1)$ & $92(8.5)$ & $127(11.7)$ & $339(31.3)$ \\
\hline & Total & $386(35.6)$ & $370(34.2)$ & $327(30.2)$ & $1083(100.0)$ \\
\hline \multirow{10}{*}{$\begin{array}{l}\text { Current job } \\
\text { status }\end{array}$} & Unemployed & $208(19.2)$ & $200(18.5)$ & $126(11.6)$ & $534(49.3)$ \\
\hline & Regular full-time employee & $49(4.5)$ & $52(4.8)$ & $30(2.8)$ & $131(12.1)$ \\
\hline & Temporary full-time employee & $54(5.0)$ & $51(4.7)$ & $92(8.5)$ & $197(18.2)$ \\
\hline & Part-time worker & $52(4.8)$ & $62(5.7)$ & $57(5.3)$ & $171(15.8)$ \\
\hline & Casual/on call/daily paid worker & $5(0.5)$ & $2(0.2)$ & $6(0.6)$ & $13(1.2)$ \\
\hline & Self-employed/own account worker & $12(1.1)$ & $2(0.2)$ & $7(0.6)$ & $21(1.9)$ \\
\hline & Contributing family worker & $3(0.3)$ & - & $3(0.3)$ & $6(0.6)$ \\
\hline & Employer hiring other workers & $2(0.2)$ & $1(0.1)$ & $6(0.6)$ & $9(0.8)$ \\
\hline & More than one employment status & $1(0.1)$ & $1(0.1)$ & - & $1(0.1)$ \\
\hline & Total & $386(35.6)$ & $370(34.3)$ & $327(30.2)$ & $1083(100.0)$ \\
\hline \multirow{7}{*}{$\begin{array}{l}\text { Duration of job } \\
\text { offer }\end{array}$} & Less than 1 week & $14(2.6)$ & $39(7.3)$ & $13(2.4)$ & $66(12.4)$ \\
\hline & Less than 1 month & $31(5.8)$ & $29(5.4)$ & $39(7.3)$ & $99(18.5)$ \\
\hline & $1-2$ months & $27(5.1)$ & $37(6.9)$ & $45(8.4)$ & $109(20.4)$ \\
\hline & 3-6 months & $49(9.2)$ & $36(6.7)$ & $54(10.1)$ & $139(26.0)$ \\
\hline & 7 months- 1 year & $25(4.7)$ & $8(1.5)$ & $17(3.2)$ & $50(9.4)$ \\
\hline & More than 1 year & $29(5.4)$ & $18(3.4)$ & $24(4.5)$ & $71(13.3)$ \\
\hline & Total & $175(32.8)$ & $167(31.3)$ & $192(36.0)$ & $534(100.0)$ \\
\hline
\end{tabular}


H1: There is a significant relationship between location and youth unemployment

H2: There is significant relationship between age and youth unemployment

H3: There is a significant relationship between gender and the youth unemployment

H4: There is significant relationship between marital status and youth unemployment

H5: There is a significant relationship between family background and youth unemployment

H6: There is a significant relationship between education and youth unemployment

H7: There is a significant relationship between training and youth unemployment

H8: There is no significant relationship between work experience and youth unemployment

H9: There is a significant relationship between migrants and youth unemployment
Based on the Table 2, the results of MLR analysis showed that at least one independent variable are significantly influenced the dependent variable (unemployment) and is significant at 5 percent significance level. The findings also show that there are differences in factors influencing unemployment in three states in the East Coast, Malaysia.

For the state of Kelantan, factors affecting youth unemployment are marital status ( $\mathrm{p}$ value: $0.005<5$ percent), family background ( $\mathrm{p}$ value: $0.075<10$ percent), work experience ( $p$ value: $0.010<5$ percent), age ( $p$ value: 0.001 $<1$ percent) and work mobility ( $\mathrm{p}$ value: $0.011<5$ percent) The regression test successfully rejected the null hypothesis and found that the five variables were determinants of youth unemployment in Kelantan. Marital status is seen as contributing to the rising number of youth unemployment in Kelantan due to not many industries offering employment to married youth compared to single youth.

Table 2: Regression Results for Factors Affecting Unemployment (East Coast)

\begin{tabular}{|c|c|c|c|}
\hline \multirow{2}{*}{ Independent Variables } & \multicolumn{3}{|c|}{ East Coast } \\
\hline & Kelantan & Pahang & Terengganu \\
\hline Location & $\begin{array}{c}0.302 \\
(0.075)\end{array}$ & $\begin{array}{c}0.670 \\
(0.030)\end{array}$ & $\begin{array}{c}0.136 \\
(-0.099)\end{array}$ \\
\hline Gender & $\begin{array}{c}0.580 \\
(-0.040)\end{array}$ & $\begin{array}{c}0.501 \\
(-0.049)\end{array}$ & $\begin{array}{c}0.002^{* \star *} \\
(0.665)\end{array}$ \\
\hline Marital Status & $\begin{array}{l}0.005^{\star *} \\
(0.493)\end{array}$ & $\begin{array}{l}0.016^{* *} \\
(0.573)\end{array}$ & $\begin{array}{c}0.059^{*} \\
(0.129)\end{array}$ \\
\hline Family Bakground & $\begin{array}{l}0.075^{*} \\
(-.124)\end{array}$ & $\begin{array}{c}0.666 \\
(0.030)\end{array}$ & $\begin{array}{c}0.258 \\
(0.075)\end{array}$ \\
\hline Education & $\begin{array}{c}0.846 \\
(-0.015)\end{array}$ & $\begin{array}{c}0.101 \\
(0.117)\end{array}$ & $\begin{array}{c}0.927 \\
(-0.006)\end{array}$ \\
\hline Training & $\begin{array}{c}0.806 \\
(0.018)\end{array}$ & $\begin{array}{c}0.737 \\
(0.024)\end{array}$ & $\begin{array}{c}0.072^{*} \\
(-0.119)\end{array}$ \\
\hline Experience & $\begin{array}{l}0.010^{* *} \\
(-0.582)\end{array}$ & $\begin{array}{l}0.000^{* * *} \\
(-1.396)\end{array}$ & $\begin{array}{l}0.000 * * * \\
(-0.906)\end{array}$ \\
\hline Age & $\begin{array}{c}0.001^{* * *} \\
(0.489)\end{array}$ & $\begin{array}{c}0.117 \\
(0.111)\end{array}$ & $\begin{array}{c}0.191 \\
(0.087)\end{array}$ \\
\hline Work Mobility & $\begin{array}{l}0.011^{* *} \\
(0.128)\end{array}$ & $\begin{array}{c}0.285 \\
(-0.074)\end{array}$ & $\begin{array}{c}0.855 \\
(0.012)\end{array}$ \\
\hline $\mathrm{R}$ Value & 0.432 & 0.437 & 0.368 \\
\hline$R$-square Value & 0.187 & 0.191 & 0.136 \\
\hline F-statistic & $9.917^{* *}$ & $19.871^{* *}$ & $15.539^{* *}$ \\
\hline $\mathrm{N}$ & 175 & 167 & 192 \\
\hline
\end{tabular}

Note: 1 . The dependent variable is the youth unemployment.

2. Statistical value - $t$ in parentheses.

3. ${ }^{* * *},{ }^{* *}$ and ${ }^{*}$ showed significant at level $1 \%, 5 \%$ and $10 \%$. 
As well as family background, findings show that youth from low income families (B40) in Kelantan find it difficult to get a job offer, thus leaving them unemployed. In line with this finding, it also shows that the factor of job mobility also affects the unemployment rate in the state. This may be due to reluctance of youths to migrate to cities and choose to work in their respective home states despite having to work outside their qualifications and low wages that they received.

However, this finding is different from the state of Pahang. The analysis found that there were only two independent variables that influence unemployment: marital status (p: $0.016<5$ percent) and work experience (p: 0.000 $<1$ percent value). Married youths find it difficult to find jobs in Pahang. This may be due to the ratio of married youths to family responsibilities and difficulty living apart if their spouse has a full-time job. Work experience is also seen as a key factor in securing a career in the state as it is seen as an important medium for choosing a job that is consistent with today's job market. While other factors such as location of residence, gender, family background, education level, attendance/course, age and mobility were found to have no significant effect on youth unemployment in Pahang.

While in Terengganu, gender factors ( $\mathrm{p}$ value: 0.002 $<1$ percent), marital status ( $\mathrm{p}$ value: $0.59<10$ percent), attendance at training/career course ( $\mathrm{p}$ value: $0.072<10$ percent) and work experience ( $\mathrm{p}$ value): $0.000<1$ percent) is a major contributing factor to youth unemployment in the state. The results of the regression analysis successfully rejected the null hypothesis and showed that all four factors were significant for youth unemployment. Young women are understood to face more problems in finding jobs in Terengganu compared to young men. This may be due to a higher proportion of female youths than male youths causing competition among them for employment. As opposed to Kelantan and Pahang, the state of Terengganu also shows that work experience and experience attending work/training courses are two of the main factors that make it difficult for youths to find employment. Experience is important in determining their careers and indirectly improves the quality and efficiency of the job industry. The more work experience and the more they attend job related courses or training, the higher are the chances of youth getting a job that will reduce the number of youth unemployment.

\section{Discussion}

The development of a conceptual framework can serve as a guide for government, private, statutory bodies and institutes to identify unemployment factors in the eastern coastal states of Kelantan, Terengganu and Pahang. In particular, it can provide recommendations on policy implications and choices for youth especially in the East Coast. The study found that factors affecting the main unemployment of the three states are marital status and work experience. It is very common that youth in the East Coast traditionally marry at a young age, which contributes to unemployment rate among young women. Being a housewife, they generally decide not to look for a job as they have to commit to their family. However, there are young married women who are looking for jobs but find it difficult with their married status. For men, responsibilities towards family members can influence their transition into the labor market. For instance, having a large number of siblings, particularly younger siblings, meaning they have to contribute financially to support the family. Bumiputera youth tend to have a larger number of siblings, as do youth in rural areas and also those from poor family backgrounds. With regard to age, the longer youth stay out of touch with the labor market, the more difficult and costly for them to return to productive employment.

Policy implications are firstly, Gender-sensitive Active Labor Market Policies (ALMPs) can effectively target disadvantaged or vulnerable groups. Using technology to enhance the effectiveness, efficiency and coverage of Active Labor Market Policies (ALMPs) ensures that specific groups of young people are not left behind. Such programs need to be community-based and offer practical skills training rather than giving academic focus. Apart from that, mentoring support would also be necessary. For example, the National Association of Women Entrepreneurs of Malaysia (NAWEM) could provide mentoring support to young women who wish to start up a business. Secondly, 'Preventive' and 'reintegration' strategies targeted at 'Not in employment, education or training (NEET) for young people identified on the basis of their neighborhood, school, family background etc. Reintegration strategies are targeted at those who have already dropped out of the education and training system.

Furthermore, the second major factor is the lack of work experience for youth in the East Coast. The shortcoming is that employers play limited role in enhancing youth employability. There should be a policy to encourage employers' organizations and chambers of commerce to make the business case to their members on their role in promoting youth employability. Employers need to be aware of why it is important and what they can do to invest in and engage with young people to create their workforce skills and talents for productivity and competitiveness. Additionally, there should be interactions between employers and education and training institutions. Employers and their organizations have central roles to play in establishing and implementing appropriate education, training and general skills requirements for the job market. Employers should also play their part in school / university boards and advisory committees; Also important is providing workbased training. Successful schemes normally involve close 
interactions where employers provide on-the-job training as part of or in addition to the formal training system; where the government provides various incentives and supports; and where there is a close alliance (industryschool partnership arrangements) between companies and training institutions.

In Terengganu, there are a number of skill shortages and mismatches. There should be more exposure on what employers require from every job applicants that include strong work ethics, good communication skills, creative and analytical thinking, problem solving skills, acting as a team player, positive attitude, learning from criticism and working under pressure. On top of that, employers should also emphasize work-based learning (WBL) to provide individuals with the skills needed to successfully obtain and keep jobs and progress in their professional development. Finally, to adopt a forward-looking approach to anticipate and match skill needs. The world of work is rapidly changing, and significant skills in workforce must adapt to new technologies and changing forms of work organization. Another factor is that youth lack entrepreneurship skills. What is needed is an effective and consistent range of support for sustainable entrepreneurship, including access to funding, information and markets; continuous mentoring support; business development services and supportive national and local regulations. Looking at national context, there should be support from organizations such as the Entrepreneurs' Organization of Malaysia, Malaysian Association of ASEAN Young Entrepreneurs and Young Entrepreneur Organization Malaysia.

Unemployment factor in terms of work mobility in Kelantan refers to migrants who take expatriate jobs. Review on country's cheap labor policy is fundamental for the country to tackle its migrant workers issues while improving jobs and incomes for young Malaysians. This measure helps to address the impact and implications of the policy on the country's productivity and growth. Another problem is the mismatch of job search and recruitment methods. Effective employment services can play important roles in anticipating and matching supply and demand for labor and skills, thus making connections between young people and employers more efficiently and systematic. Next is to ensure that employment services are available where they are most needed. Strengthening the outreach of employment services would benefit youth who are living in a disadvantaged situation in rural areas and East Malaysia where internet access is low and communication with cities is limited. It is particularly important for the benefits of youth in rural areas, it is very useful to integrate services and encourage co-location of service providers to deliver employment support from small centers more economically viable and more joined-up for the clients (one-stop shops).

\section{Conclusion}

Career planning is important to ensure that youth are prepared before they begin their career pursuit and avoid being unemployed. This plan includes experience in attending courses or career training as well as getting career counselling from family, teachers, lecturers and other related parties. Overall, the study found that the majority of youth respondents in the East Coast states of Malaysia are still unemployed and are actively seeking employment. The findings also show that there are differences in factors affecting youth unemployment in the three states of the East Coast, Malaysia. Therefore, in the face of the challenges of today's job market, youths should be wise in preparing for their career by choosing the right career as well as doing side jobs to gain experience before they pursuit for a real job. It is a crucial for them to avoid unemployment at a young age.

\section{Disclosure statement}

No potential conflict of interest was reported by the author.

\section{References}

Abugamea, G. (2018). Determinants of Unemployment: Empirical Evidence from Palestine. MPRA Paper No. 89424. Munich Personal RePEc Archive (MPRA). Retrieved November 21, 2019 from https://mpra.ub.uni-muenchen.de/89424/.

Aida, B., Norailis, A. W., \& Rozaini, R. (2015). Critical Success Factor of Graduate Employability Programs. Journal of Economic, Business and Management, 3(8), 767 - 771.

Bakar, M. Z. A., \& Bakar, S. A. (2020). Prudent Financial Management Practices among Malaysian Youth: The Moderating Roles of Financial Education. Journal of Asian Finance, Economics and Business, 7(6), 525-535. DOI: https:// doi.org/10.13106/jafeb.2020.vol7.no6.525.

Camba, A. L. (2020). Estimating the Nature of Relationship of Entrepreneurship and Business Confidence on Youth Unemployment in the Philippines. Journal of Asian Finance, Economics and Business, 7(8), 533-542. DOI: https://doi. org/10.13106/jafeb.2020.vol7.no8.533

Carabelli, G., \& Lyon, D. (2016). Young People's Orientations to the Future: Navigating the Present and Imagining the Future. Journal of Youth Studies, 19(8), 1110 - 1127.

Cassells, R., \& Duncan, A. (2020). Job Keeper Payment: How Will It Work, Who Will Miss Out and How Get It?. Curtin University. Retrieved May 10, 2020 from: https://theconversation.com/ jobkeeper-payment-how-will-it-work-who-will-miss-out-andhow-to-get-it-135189.

Department of Statistic Malaysia. DOSM. (2019a). Current Population Estimates, Malaysia, 2018 2019. Department of Statistic Malaysia. Retrieved 
February 4, 2020 from https://www.dosm.gov.my/v1/ index.php? $\mathrm{r}=$ column/cthemeByCat\&cat $=155 \&$ bul id=aWJZRkJ4UEdKcUZpT2tVT090Snpydz09\&menu_id=L0pheU43NWJwRWVSZklWdzQ4TlhUUT09

Department of Statistic Malaysia. DOSM. (2019b). Key Statistics of Labour Force in Malaysia, July 2019. Department of Statistic Malaysia. Retrieved February 4, 2020 from https://dosm.gov. my/ v1/index.php? $r=$ column/cthemeByCat\&cat=124\&bul id=eWtsKy9TL3NnSjd1N1JUdkNZYndUUT09\&menu_ id=Tm8zcnRjdVRNWWlpWjRlbmtlaDk1UT09

Department of Statistic Malaysia. DOSM. (2019c). Key Statistics of Labour Force in Malaysia, October 2019. Department of Statistic Malaysia. Retrieved February 4, 2020 from https:// www.dosm.gov.my/v1/index.php?r=column/pdfPrev\&id= ZkhCUHpVT0NkbnliUVFITjBwUG1qdz09\#: :text=The $\% 20$ labour $\% 20$ force $\% 20$ participation $\% 20$ rate, 2018\%20to\%20 $15.78 \% 20$ million $\% 20$ persons.

Department of Statistic Malaysia. DOSM. (2018a). Labour Force Survey Report, Malaysia, April 2019. Department of Statistic Malaysia. Retrieved February 4, 2020 from https://www.dosm.gov.my/ v1/index. php?r=column/pdfPrev\&id=SFNjK1VQb1prbWxY Q2pyN05CNFpRUT09\#: :text=The $\% 20$ number\%20of $\% 20$ labour $\% 20$ force,cent $\% 20$ to $\% 2015.09 \% 20$ million $\% 20$ persons.\&text $=$ The $\% 20$ unemployment $\% 20$ rate $\% 20 \mathrm{in} \% 20$ April,for $\% 20$ the $\% 20$ two $\% 20$ consecutive $\% 20$ months.

Department of Statistic Malaysia. DOSM. (2018b). Graduate Statistics 2018, December 2019. Department of Statistic Malaysia. Retrieved February 4, 2020 from https://www.dosm.gov.my/ v1/index.php/ index.php? $\mathrm{r}=\mathrm{column} / \mathrm{cthemeByCat} \& \mathrm{cat}=476 \& \mathrm{bul}$ $\mathrm{id}=\mathrm{cDJkZjM}$ 5b2hjdjJZMDlvNDlueU54Zz09\&menu_ $\mathrm{id}=$ Tm8zcnRjdVRNWWlpWjRlbmtlaDk1UT09

Dorsett, R., \& Lucchino, P. (2015). The School-To-Work Transition: An Overview of Two Recent Studies. National Institute of Economic and Social Research. Discussion Paper No. 445. Retrieved June 6, 2019 from https://www.niesr.ac.uk/ sites/ default/files/publications/dp445.pdf

European Commission. (2014). Erasmus. Facts, Figures and Trends. The European Union Support for Student and Staff Exchanges and University Cooperation in 2012-2013. Luxembourg: Publications Office of the European Union.

Eriksson, S., \& Gottfries, N. (2005). Ranking of Job Applicants, on-the-Job Search, and Persistent Unemployment. Labour Economics, 12, 407-428. https://doi.org/10.1016/j. labeco.2003.11.008.

Ginzberg, E. (1972). Toward a theory of occupational choice: A restatement. Vocational Guidance Quarterly, 20, 169-176. https://doi.org/10.1002/j.2164-585X.1972.tb02037.x

Haar, B. T. (2018). Discrimination of Young Workers: To be Justified or not to be Justified? International Labor Rights Case Law, 4, $230-234$.

Hamed, A. M., Sajad, R., \& Muslim, A. (2015). Examining Job Seekers' Perception and Behavioural Intention Toward Online
Recruitment: A PLS Path Modelling Approach. Journal of Global Business Advancement, 8(3), 305 - 325.

Hedvicakova, M. (2018). Unemployment and effects of the first work experience of university graduates on their idea of a job. Applied Economics, 50(31), 3357 - 3363.

Hooker, S., \& Brand, B. (2010). College knowledge: A critical component of college and career readiness. New Directions for Youth Development, 127, 75-85. doi:10.1002/yd.364.

Hussain, N. E., Abdullah, N., \& Abdullah, H. (2015). The Relationship between Internal Migration and its Migration Factors: Case Study in Malaysia. Malaysian Journal of Economics, 49(2), 121 - 133.

Institute for Youth Research Malaysia. IYRES. (2019). Statistics of Population and Youth Population by Gender, Ethnic and District in Malaysia by 2013 - 2019 year. Malaysia Youth Data Bank System. Retrieved July 4, 2019 from https://ydata.iyres. gov.my/.

Institute for Youth Research Malaysia. IYRES. (2017). Malaysia Youth Statistics: Data for 2017: Volume 5. Institute for Youth Research Malaysia (IYRES). Ministry of Youth and Sports. Retrieved Mac 16, 2019 from http://ebelia.iyres.gov.my/ publishing

Ismail, M. S., Yusoff, S. H. M., Embing, R., Jusoh, W. H. W., Shuhari, M. H., Abdullah, S. S., \& Yahaya, A. (2019). The Influence of Study Stream on Carrier Self-Efficacy Among Secondary School Students. International Journal of Asian Social Science, 9(7), 534-545.

Ministry of Finance. MoF. (2019). Economic Outlook 2019. Ministry of Finance Malaysia. Retrieved January 2, 2020 from https://www.treasury.gov.my/pdf/economy/2019/chapter2.pdf

Kamaruddin, S. N. A. A., Omar, K., Saputra, J., Shakur, E. S. A., Rahim, N. A. A. A., Razali, M. K. A. M. (2020). Determinants of Female Employees' Job Performance in Malaysia. Management Science Letters, 11(2021), 233-238.

Khazanah Research Institute. KRI. (2018). The School-to-Work Transition of Young Malaysians. Kuala Lumpur: Khazanah Research Institute.

Kruppe, T., \& Lang, J. (2018). Labour Market Effects of Retraining for The Unemployed: The Role of Occupations. Applied Economics, 50(14), 1578-1600.

Lancee, B. (2019). Ethnic Discrimination in Hiring: Comparing Groups Across Contexts. Results from A Cross-National Field Experiment. Journal of Ethnic and Migration Studies. DOI: 10.1080/1369183X.2019.1622744.

Lögdberg, U., Nilsson, B., \& Kostenius, C. (2018). Thinking About the Future, What's Gonna Happen? : How Young People In Sweden Who Neither Work Nor Study Perceive Life Experiences In Relation To Health And Well-Being. International Journal of Qualitative Studies on Health and Well-being, 13(1), $1-12$.

Longhi, S., \& Taylor, M. (2013). Employed and Unemployed Job Seekers and the Business Cycle. Oxford Bulletin of Economics and Statistics, 76, 4. https://doi.org/10.1111/obes.12029 
Malaysian Industrial Development Finance. MIDF. (2018). MIDF Research: Youth Unemployment Rate Remains High as Skills Mismatch Stay Prevalent. Malaysian Industrial Development Finance. Retrieved December 10, 2019 from http://www. midf.com.my/images/Downloads/Research/Econs-Msia-2017Youth-UE-MIDF-030518.pdf.

Mansor, M., \& Rashid, A. M. R. (2016). The Relationship Between Career Readiness and Student Career Maturity Malaysian Public Skills Training Institution. Skills Malaysia Journal, 2(1), $27-33$.

Mol, C. V. (2016). Migration Aspirations of European Youth in Times of Crisis. Journal of Youth Studies, 19(10), 1303 - 1320.

Mustapa, K., \& Abdullah, S. S. (2019). Career Experience as a Male Nurse. Journal of Business and Social Development, 7(1), 1 - 8.

Parson, F. (1909). Choosing A Vocation. Boston, MA: Houghton Mifflin.

Patacchini, E. \& Zenou, Y. (2012). Ethnic networks and employment outcomes. Regional Science and Urban Economics, 42(6), $938-949$.

Pheko, M. M., \& Molefhe, K. (2017). Addressing Employability Challenges: A Framework for Improving the Employability of Graduates in Botswana. International Journal of Adolescence and Youth, 22(4), 455 - 469. DOI: $10.1080 / 02673843.2016 .1234401$.

Roberts, S., \& Zhen, L. (2017). Capital Limits: Social Class, Motivations for Term-Time Job Searching and the Consequences of Joblessness among UK University Students. Journal of Youth Studies, 20(6), 732 - 749.

Sharf, R. S. (1996). Theories of personality and counseling: Concept and cases (2nd ed.). Pacific Grove: Brooks/Cole.

Stanley, D., Beament, T., Falconer, D., Haigh, M., Newton, R., Stanley, K., \& Wall, P. (2014). Profile and Perceptions of Men in Nursing in Western Australia- Research Report 2014. Perth, Australia: UWAPrint.

Stuth, S., \& Jahn, K. (2020). Young, successful, precarious? Precariousness at the entry stage of employment careers in Germany. Journal of Youth Studies, 23(6), 702 - 725. DOI: 10.1080/13676261.2019.1636945.

Super, D. E. (1969). Vocational development theory: Persons, positions, and process. The Counseling Psychologist, 1(1), $2-9$.
Tåhlin, M., \& Westerman, J. (2020). Youth employment decline and the structural change of skill. European Societies, 22(1), 47 - 76. DOI: 10.1080/14616696.2018.1552981.

Vandenbrande, T., Coppin, L., van der Hallen, P., Ester, P., Fourage, D., Fasang, A., Geerdes, S., \& Schömann, K. (2006). Mobility in Europe: Analysis of the 2005 Eurobarometer Survey on Geographical and Labour Market Mobility. Luxembourg: European Foundation for the Improvement of Living and Working Conditions.

Wilde, R. J., \& Leonard, P. (2018). Youth Enterprise: The Role of Gender and Life Stage in Motivations, Aspirations and Measures of Success. Journal of Education and Work, 31(2), $144-158$.

World Economic Forum. WEF. (2014). Matching Skills and Labor Market Needs: Building Social Partnerships for Better Skills and Better Jobs. The Global Agenda Council on Employment. Retrieved January 16, 2019 from http://www3. weforum.org/ docs/GAC/2014/WEF_GAC_Employment MatchingSkillsLabourMarket_Report_2014.pdf

Wulandari, D., Utomo, S. H., Narmaditya, B. S., \& Kamaludin, M. (2019). Nexus between Inflation and Unemployment: Evidence from Indonesia. Journal of Asian Finance, Economics and Business, 6(2), 269 - 275. doi:10.13106/jafeb.2019.vol6. no2.269

Xiaoya, S. D., \& Tay, N. S. P. (2016). Some Challenges to Economic Growth and Stability in China. The Chinese Economy, 49(5), 301-306.

Yerkes, M., van de Schoot, R. \& Sonneveld, H. (2012). Who are the Job Seekers? Explaining Unemployment among Doctoral Recipients. International Journal of Doctoral Studies, 7, 153 - 166

Zuccotti, C. V. (2015). Do Parents Matter? Revisiting Ethnic Penalties in Occupation among Second Generation Ethnic Minorities in England and Wales. Sociology, 49(2), 229-251.

Zwysen, W., \& Longhi, S (2018). Employment and Earning Differences in the Early Career of Ethnic Minority British Graduates: The Importance of University Career, Parental Background and Area Characteristics. Journal of Ethnic and Migration Studies, 44(1), 154-172. 